\title{
CONSISTENCY OF POTATO-STARCH SIZE ${ }^{1}$
}

\author{
By Walter T. Schreiber, M. N. V. Geib, and O. C. Moore
}

\section{ABSTRACT}

The physical characteristics imparted to cotton-warp yarn in the so-called "slashing" or sizing operation are dependent in part upon the consistency of the starch size used in the processing. In textile mill practice, the size is heated and agitated from the time it is prepared until it is consumed. The potato-starch sizes, however, are more or less unstable, and continuous heating and agitation tends to cause a decrease in the consistency of the size.

Laboratory experiments show that the decrease in consistency of size is dependent upon the temperature of cooking, speed of agitation, and length of the cooking period.

It seemed reasonable to suppose that the decrease in consistency of sweetpotato-starch size may be due to the catalytic action of liquefying enzymes of amylase which may be present in the starch. Although various treatments calculated to remove or destroy such enzymes failed to stabilize the consistency, the addition of a solution containing small quantities of dispersed lecithin and lanum to the sweetpotato-starch size materially retarded the decrease in consistency. The reason for this action is not yet clear.

The consistency of sweetpotato-starch size can be greatly increased by washing the starch with certain simple solutions.

CONTENTS

I. Introduction

II. Apparatus and procedure

III. Preliminary work

IV. Attempts at stabilization of sweetpotato-starch size

V. Discussion

\section{INTRODUCTION}

Starch is used extensively in the textile industry for sizing warp yarns. This is done to increase the abrasive resistance of the yarns, to give them added body, and to increase their weight.

In mill practice this sizing operation is carried out in a "slasher." In this machine, the yarns are first passed through a vat containing a hot suspension of starch in water, called the "size", pressed between rollers, and dried by passing over or around one or more steam-heated cylinders. A starch pot for preparing the size and storage tanks for the latter complete the slasher equipment. The pot and tanks are equipped with both open and closed steam coils and agitators.

The size is prepared by cooking and agitating a mixture of starch and water, either with or without other ingredients, until the starch is thoroughly gelatinized and a uniform mixture is obtained. This mixture is then transferred to the storage tank where it is held at

1 This study was carried out in the laboratories of, and in cooperation with, the Alabama Polytechnic Institute, Auburn, Ala. The Carbohydrate Division of the Bureau of Chemistry and Soils in the U.S. Department of Agriculture also cooperated in providing some of the sweetpotato starch used in this wrork. 
constant temperature by heating with steam and is agitated to maintain uniform concentration. From the storage tank the size is either added continuously to the sizing vat as fast as it is consumed in the process or it is circulated from the storage tank through the sizing vat and back to the storage tank. The size is thus heated and agitated from the time it is prepared until it is consumed. The physical characteristics of sized yarn are materially affected by the consistency

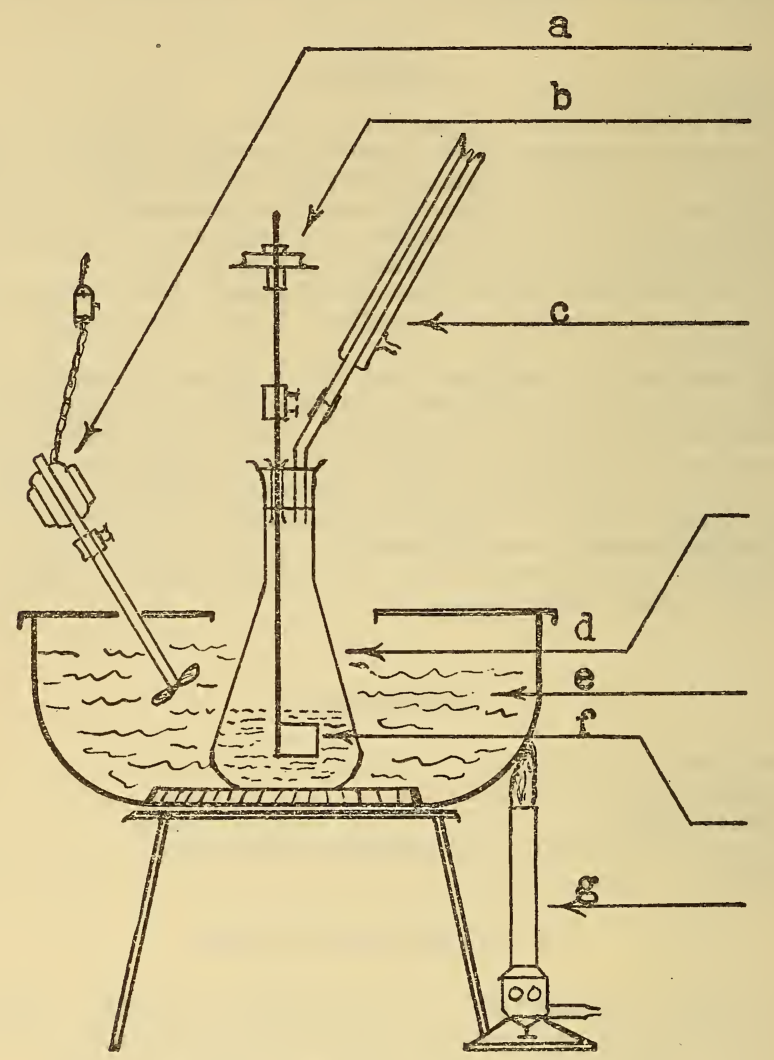

Figure 1.-Starch paste apparatus

$$
\begin{aligned}
& \mathrm{a}=\text { Oil stirrer } \\
& \mathrm{b}=\text { Pulley } \\
& \mathrm{c}=\text { Water condenser } \\
& \mathrm{d}=\text { Erlenmeyer flask }(200 \mathrm{cc}) \\
& \mathrm{e}=\text { Oil bath } \\
& \mathrm{f}=\text { Starch paddle } \\
& \mathrm{g}=\text { Burner }
\end{aligned}
$$

of the size. ${ }^{2}$ This consistency decreases (the solution gets thinner) markedly with prolonged heating and stirring, ${ }^{3}$ particularly when noncereal starches are used; and since, in commercial practice, as explained above, it is customary to subject the size to prolonged heating and agitation, it follows that the maintenance of uniform quality in the sized yarn is difficult, if not impossible.

\footnotetext{
2 Farrow and Jones, An Examination of the Process of Sizing Cotton Yarns on an Experimental Tape Frame, J.Text.Inst., vol. 18, T3, 1927.

3 Ripperton, Physico-Chemical Properties of Edible Cana and Potato Starches, Hawaii Exp. Sta., Bull. 63 .
} 
The purpose of the present study was to determine the effect of different variables on the consistency of potato-starch size, and, if possible, to find some means of preventing or decreasing the change in consistency under the above conditions.

\section{APPARATUS AND PROCEDURE}

The conditions encountered in mill practice were simulated, as far as practicable, in the apparatus used for the experimental cooking. This is shown diagramatically in figure 1 . With this set-up it was possible to regulate the temperature as well as the rate of agitation, and thus to reproduce any given cooking conditions.

The general procedure was as follows: A sample of starch equivalent to $4.5 \mathrm{~g}$ of bone-dry material was placed in a $200 \mathrm{ml}$ Erlenmeyer flask with $100 \mathrm{ml}$ of distilled water and immersed in the heated-oil bath. The paddle was operated at 150 r.p.m. and the oil bath was

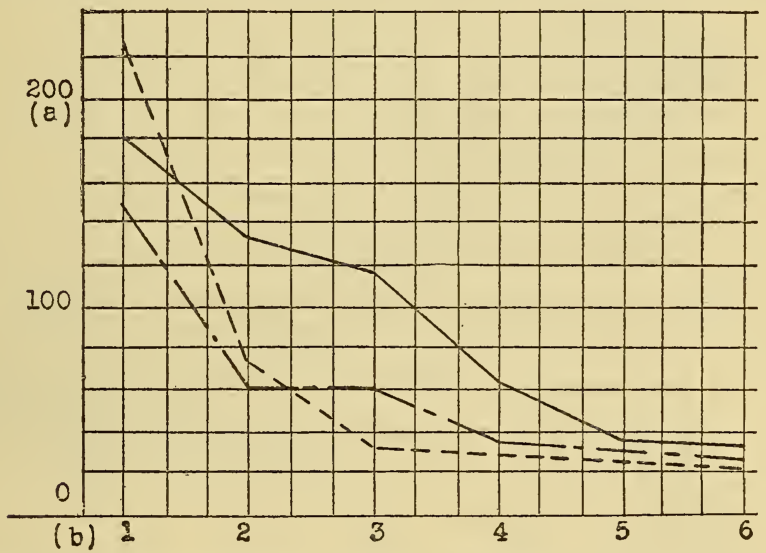

FIGURE 2.-Effect of time of cook on consistency of starch sizes

(a) =Time of flow of $20 \mathrm{cc}$ through viscosimeter in seconds

(b) = Time of cook, hours

- Sweetpotato starch (A.P.I.)

- - - Irish-potato starch

_- - Sweetpotato starch (Dept. of Agriculture)

Cook temperature, $105^{\circ} \mathrm{C}$.

Speed of agitation, 150 r.p.m.

Time of cook, $1,2,3,4,5$, and 6 hours.

maintained at $105^{\circ} \mathrm{C}$. throughout the cooking, except as otherwise indicated. The temperature of the mixture inside the flask was approximately $5^{\circ} \mathrm{C}$. lower than that of the oil bath, but the temperature of the oil bath is the one shown on the curves.

To determine the so-called consistency of the size, a Saybolt viscosimeter ${ }^{4}$ was used. During the determination the temperature of the viscosimeter was held at $95^{\circ}$ C. ${ }^{5}$ The times required for $5,10,15$, and $20 \mathrm{ml}$ of size to flow through the orifice were observed, but it was sufficient to use only the last as a measure of the consistency.

\section{PRELIMINARY WORK}

A series of preliminary experiments was carried out, the results of which are shown graphically in figures 2 to 5 , inclusive.

\footnotetext{
4 Twenty-six seconds were required for $60 \mathrm{cc}$ of distilled water to flow through the viscosimeter at a temperature of $95^{\circ} \mathrm{C}$.

This temperature was used in all determinations throughout this investigation.
} 
Figure 2 shows the effect of prolonged cooking on the consistency of various starches. Three different starches were used in these experiments, namely, a sweetpotato starch made at the Alabama Polytechnic Institute, Auburn, Ala., designated A.P.I.; another sweetpotato starch made by the Carbohydrate Division of the Bureau of Chemistry and Soils, United States Department of Agriculture, and an irish-potato starch. The temperature of the oil bath, the speed of agitation, and the concentration of the size were uniform throughout this series. Determinations of consistency were made at 1-hour intervals over a 6-hour cooking period. The results show that prolonged heating causes a decided decrease in the consistency of all the samples and that the rate of this breakdown varies with the individual starches and is slowest with sweetpotato size.

The effect of different cooking temperatures on the consistency of three samples of sweetpotato-starch size is shown in figure 3 . The

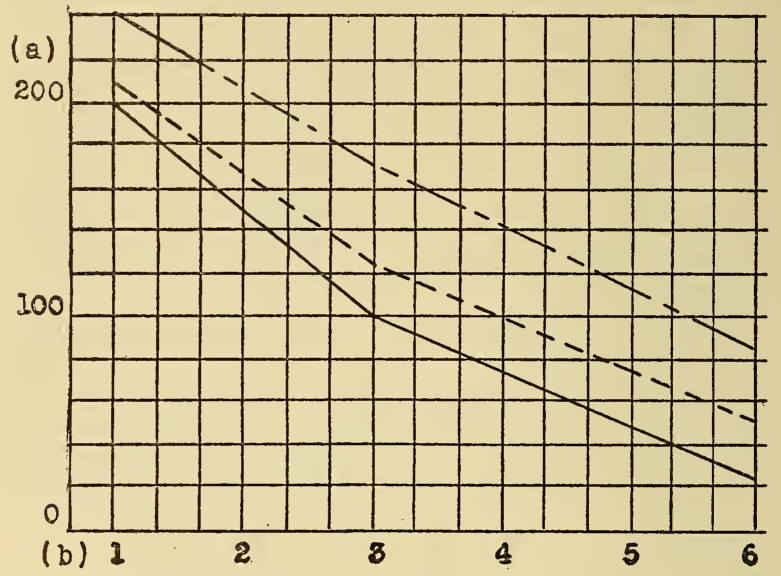

FIGURE 3.-Effect of temperature of cook on consistency of sweetpotato-starch size

(a) $=$ Time of flow of $20 \mathrm{cc}$ through viscosimeter in seconds

(b) = Time of cook, hours

Cook temperature, $105^{\circ} \mathrm{C}$.

- Cook temperature, $95^{\circ} \mathrm{C}$.

Cook temperature, $90^{\circ} \mathrm{C}$.

Speed of agitation, 150 r.p.m.

Time of cook, 1,3 , and 6 hours.

speed of agitation and the concentrations of the mixtures were kept uniform in these runs, while the temperature of the oil bath was maintained at $105^{\circ}, 95^{\circ}$, and $90^{\circ}$ C., respectively. Determinations of consistency were made at the end of 1,3 , and 6 hours of cooking. The results show that the higher temperatures produce a size of lower consistency.

Figure 4 shows the effect of agitation during the cooking period on the consistency of sweetpotato-starch size. The samples, each $4.5 \mathrm{~g}$ of A.P.I. sweetpotato starch plus $100 \mathrm{ml}$ of water, were cooked at an oil-bath temperature of $105^{\circ} \mathrm{C}$, with the speeds of agitation maintained at 150 and 270 r.p.m., respectively. Consistency determinations were made at 1-, 3-, and 6-hour intervals over a 6 -hour cooking period. These determinations apparently show that after gelatinization of the starch has been brought about, the more severe agitation during cooking causes a more rapid decrease in the consistency of the size. 
The effect of age of the sweetpotato starch on the consistency of size made therefrom is shown in figure 5. Batches of size were made from the same sample of starch at 6-month intervals during 18 months.

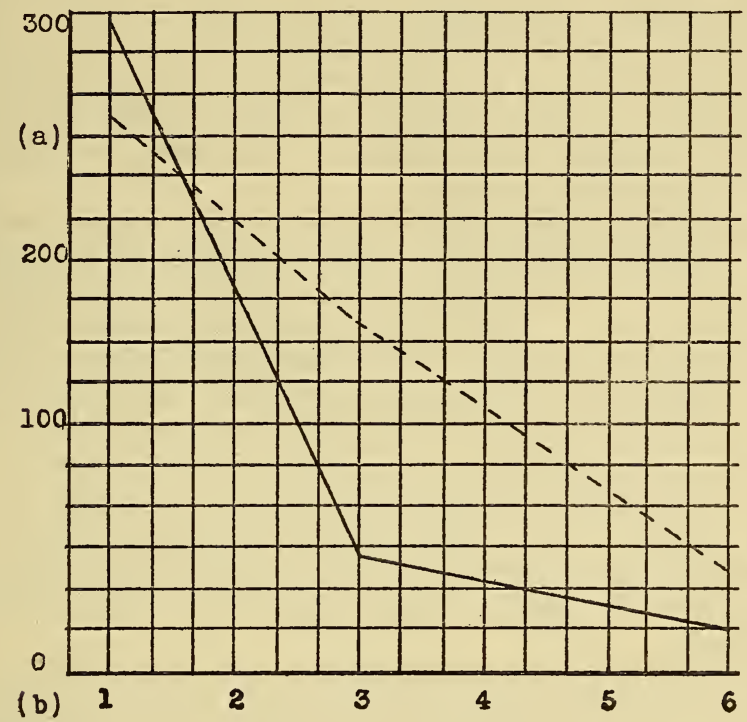

FIGURE 4.-Effect of severe agitation on consistency of sweetpotato-starch size

(a) Time of flow of $20 \mathrm{cc}$ through viscosimeter in seconds.

(b) Time of cook, hours.

- Speed of agitation, 270 r.p.m.

Cook temperature, $105^{\circ} \mathrm{C}$.

Time of cook, 1, 3, and 6 hours.

200

(a)

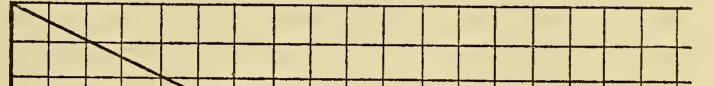

100

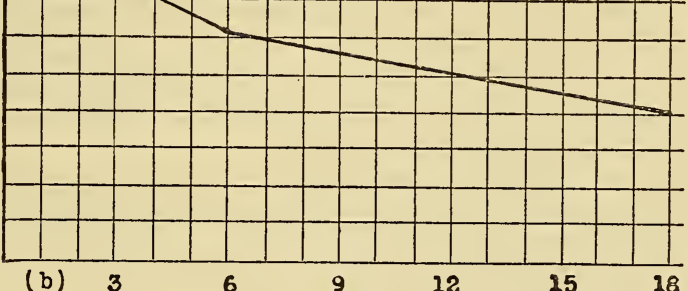

FigURE 5.-The consistency of starch size made from sweetpotato starch aged for various time periods

(a) Time of flow of $20 \mathrm{cc}$ through viscosimeter in seconds.

(b) Aging periods, months.

Rate of agitation, 150 r.p.m.

Cook temperature, $105^{\circ} \mathrm{C}$.

Time of cook, 3 hours.

Determinations at $0,6,12$, and 18 months.

The data show that in the case of this particular lot of sweetpotato starch the consistency of the size decreased as the age of the starch increased. 


\section{ATTEMPTS AT STABILIZATION OF SWEETPOTATO- STARCH SIZE}

There seems to be no generally accepted theory regarding the behavior of starch when heated with water. ${ }^{7} 891011$ The present investigation was projected on the theory that the breakdown of the starch size on prolonged heating is due to the presence of a small amount of amylase in the starch.12 13 The experiments were therefore designed to find some means of removing or destroying this enzyme or of inhibiting its action.

The first method employed to inhibit enzyme action was the use of heat. ${ }^{14} 1516$ Sweetpotato starch was heated, both in the dry and in the wet state, for various periods of time at temperatures ranging from $105^{\circ}$ to $175^{\circ} \mathrm{C}$. In no case did this treatment of the starch materially affect the stability of the size subsequently made therefrom.

Various materials - naphthalene, resorcin, thymol, formaldehyde, copper sulphate, silver nitrate, and mercuric chloride-in concentrations of 0.1 and 0.4 percent of the weight of starch were added to a sweetpotato-starch-water mixture previous to cooking, in an effort to inhibit the action of any enzyme which might be present. ${ }^{17} 1819$ No improvement in the properties of the size made from this starch was noted, however; in fact, in most cases the added chemical made matters worse.

The sweetpotato starch was subjected to various methods of purification in an effort to remove any enzyme which might be present. The first treatment consisted of washing the sweetpotato starch successively with sulphurous acid (having a $\mathrm{pH}$ value of 2.6 ) and water; then with a 0.5 percent solution of sodium hydroxide, followed again by water; with acetic acid (having a $\mathrm{pH}$ of 2.8 ); and finally with water. Samples were taken after each water wash. In another set of experiments the original starch was washed with saturated solutions of calcium carbonate and trisodium phosphate, respectively. Another sample was repeatedly washed with 50 percent alcohol, then with 10 percent glycerin, and finally with water. ${ }^{20}{ }^{21}$ The consistency of sizes made from the above samples differed but slightly from that of size made from the original.

Treatment of the sweetpotato starch with solutions of soluble starch containing sodium chloride was also tried. ${ }^{22}$ Details of two typical starch-salt treatments follow.

Treatment A.- Twenty grams of sweetpotato starch were agitated for 1.5 hours with $250 \mathrm{ml}$ of a solution containing 1 percent of soluble

${ }^{6}$ Alsberg, Studies upon Starch, Ind. Eng. Chem., vol. 18, p. 190, 1926.

7 Freundlich, Colloid and Capillary Chemistry, p. 625.

8 Malfitano, Alexander, Colloid Chemistry, vol. 4, p. 167.

9 Meyers, Ibid.

10 Bancroft, Applied Colloid Chemistry, p. 192.

11 Tiebackx, Notes on Starch, Phar. Weekblad., vol. 60, pp. 338-39, 1923.

12 Gore, Occurrence of Diastase in the Sweetpotato in Relation to the Preparation of Sweetpotato Sirup,

J. Bio. Chem., vol. 44, p. 19, 1920 .

${ }_{13}$ U.S. Department of Agriculture Year Book, 1929-30, p. 503.

${ }_{14}$ Luers and Lorniser, Inactivation of Malt Amylase by Heat and Irradiation.

15 Chrzaszcz, Effect of Temperature on Action of Amylase. Bio. Chem. z., vol. 142, pp. 417-39, 1923.

16 Thorpe, Dictionary of Applied Chemistry, vol. 3, p. 131.

17 Chrzaszcz and Joscht, Inhibition of Single Amyloclastic Function of Amylase of Malt Produced by Keeping in Presence of Various Reagents. Bio. Chem. 2, vol. 80, pp. 211-14, 1921.

18 Euler and Svanberg, Fermentforschung, vol. 3, p. 330, 1920, vol. 4, pp. 29, 142, 90, 1921.

${ }_{19}$ Olsson, Poisoning of Amylase with Heavy Metals and Organic Compounds, Hoppe-Seylers Zeitsch für Physiol. Chemie., vol. 117, p. 97,1921.

20 Sherman and Schlesinger, J.Am.Chem.Soc. vol. 37, p. 643, 1915.

21 Thorpe, Dictionary of Applied Chemistry, vol. 3, p. 131.

${ }^{22}$ Ambard, Amylase, Its Estimation and Mechanism of Its Action, Bull. Soc. Chim. Biol. vol. 3, pp. 51-65, 1921. 
starch and 0.5 percent of $\mathrm{NaCl}$. The mixture was allowed to settle, and the liquid decanted. This treatment was repeated three times and the resulting starch was finally washed with water, filtered, and dried at $50^{\circ} \mathrm{C}$.

Treatment B.-Twenty grams of sweetpotato starch were agitated for 40 minutes with $300 \mathrm{ml}$ of water containing $6 \mathrm{~g}$ of rice starch, $0.6 \mathrm{~g}$ of $\mathrm{NaCl}$, and $1.2 \mathrm{~g}$ of disodium phosphate. The mixture was then centrifuged and the supernatant liquid decanted. This treatment was repeated twice, after which the starch was washed, filtered, and dried at $50^{\circ} \mathrm{C}$.

The curves in figure 6 show that the consistency of sizes obtained from the starch thus treated was much greater than that of the control sample, although the rate of breakdown was not materially affected. This method shows great promise.

It has been shown by Sorensen ${ }^{23}$ that the $\mathrm{pH}$ is an important factor in enzymic action, affecting both the rate of reaction and the rate of

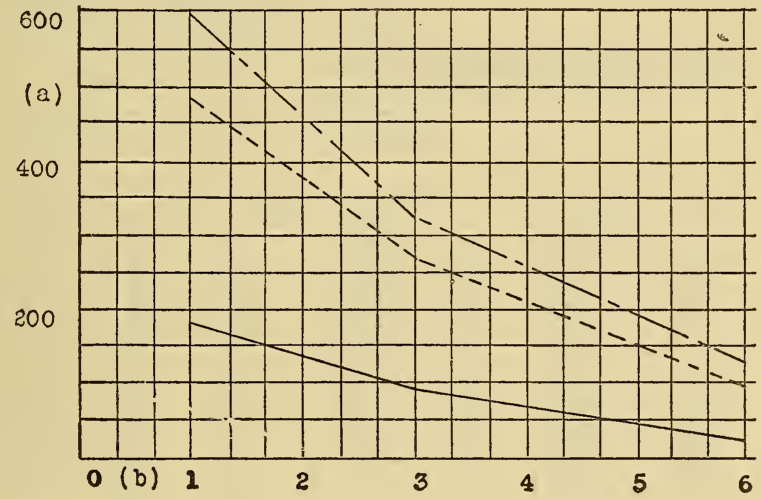

FIGURE 6.-Effect of consistency of sweetpotato-starch size of treatment with solutions of soluble starch and certain saits

(a) $=$ Time of flow of $200 \mathrm{cc}$ through viscosimeter in seconds.

(b) = Time of cook, hours.

Untreated starch.

- - - Treatment A.

-- Treatment B.

Cook temperature, $105^{\circ} \mathrm{C}$.

Speed of agitation, 150 r.p.m.

Time of cook, 1,3 , and 6 hours.

inactivation of enzymes. It is also known that the acidity has a direct influence on the hydrolysis of starch and other carbohydrates.

Accordingly the relation of $\mathrm{pH}$ to the consistency of the sweetpotato starch size was studied. The starch mixtures consisted of $95 \mathrm{ml}$ of water, $5 \mathrm{ml}$ of a buffering solution prepared according to McIlvaine ${ }^{24}$, and $4.5 \mathrm{~g}$ of starch. Buffering solutions having $\mathrm{pH}$ values of $3,4,5,6,7$, and 8 were used. The addition of the buffer solutions, however, did not appreciably retard the breakdown of the sweetpotato starch during the cooking operation.

Sueyoski and Aoke ${ }^{25}$ report that colloidal solutions of lecithin inhibit the action of amylase, and Truszkowski ${ }^{26}$ says that amylase is absorbed by lipoids.

${ }^{23}$ Sorensen, Bio. Chem. Zeitsch., vol. 22, p. 352, 1910; vol. 21, pp. 131, 279, 1909.

24 Clark, The Determination of Hydrogen Ions, p. 116.

25 Sueyoski and Aoke, Influence of Lipoids, Phospholipins on Action of Enzymes, Sei-ipkawi Mcd. J., vol. 48, no. 8 .

${ }_{20}$ Truszkowsky, Structure of Enzyme Action, Bio. Chem. J., vol. 22, pp. 767-72. 
These claims suggested the use of cholesterol (lanum) and lecithin in the size mixtures, as possible inhibiting agents.

The lecithin-lanum solutions were prepared by adding a given weight of lecithin to a measured volume of distilled water and vigorously agitating with a high-speed mixer at a temperature of $50^{\circ} \mathrm{C}$. After the lecithin was thoroughly dispersed, a given weight of lanum was added and the solution again thoroughly mixed. Definite volumes of these solutions were added to the starch sample $(4.5 \mathrm{~g})$ and distilled water was added to make the total volume of the mixture $100 \mathrm{ml}$. This mixture in turn was cooked as indicated in table 1, which gives data showing the effect of these reagents on the stability of sweetpotato-starch size.

TABLE 1.-Effect of various cooking temperatures on sweetpotato starch to which small quantities of lecithin ${ }^{a}$ and lanum ${ }^{b}$ have been added

\begin{tabular}{|c|c|c|c|c|c|c|}
\hline \multirow{3}{*}{$\begin{array}{l}\text { Weight } \\
\text { of lecithin }\end{array}$} & \multirow{3}{*}{$\begin{array}{l}\text { Weight } \\
\text { of lanum }\end{array}$} & \multirow{3}{*}{$\begin{array}{l}\text { Ratio of } \\
\text { lecithin } \\
\text { to lanum }\end{array}$} & \multirow{3}{*}{$\begin{array}{l}\text { Amount } \\
\text { of leci- } \\
\text { thin-lan- } \\
\text { um as per } \\
\text { centage } \\
\text { by weight } \\
\text { of starch }\end{array}$} & \multicolumn{3}{|c|}{$\begin{array}{l}\text { Loss of consistency between } \\
3 \text { and } 6 \text { hours of cooking }\end{array}$} \\
\hline & & & & \multicolumn{3}{|c|}{ Cooking temperature } \\
\hline & & & & $105^{\circ} \mathrm{C}$. & $95^{\circ} \mathrm{C}$. & $90^{\circ} \mathrm{C}$. \\
\hline $\begin{array}{l}\text { Grams } \\
0.1355 \\
.2710 \\
.1355 \\
.0677 \\
.2710 \\
.1355 \\
.0677 \\
.2710 \\
.1355 \\
.0677 \\
.2710 \\
.1355 \\
.0677 \\
.1355\end{array}$ & $\begin{array}{c}\text { Grams } \\
0.0170 \\
.0380 \\
.0193 \\
.0097 \\
.0450 \\
.0225 \\
.0112 \\
.0540 \\
.0275 \\
.0125 \\
.0680 \\
.0338 \\
.0170 \\
.0450\end{array}$ & $\begin{array}{l}8: 1 \\
7: 1 \\
7: 1 \\
7: 1 \\
6: 1 \\
6: 1 \\
6: 1 \\
5: 1 \\
5: 1 \\
5: 1 \\
4: 1 \\
4: 1 \\
4: 1 \\
3: 1\end{array}$ & $\begin{array}{c}\text { Percent } \\
3.39 \\
6.89 \\
3.44 \\
1.72 \\
7.02 \\
3.51 \\
1.75 \\
7.24 \\
3.62 \\
1.81 \\
7.52 \\
3.76 \\
1.88 \\
4.01\end{array}$ & $\begin{array}{c}\text { Percent } \\
61 \\
52 \\
62 \\
68 \\
35 \\
61 \\
68 \\
58 \\
73 \\
70 \\
46 \\
60 \\
71 \\
60\end{array}$ & $\begin{array}{r}\text { Percent } \\
40 \\
38 \\
32 \\
48 \\
28 \\
27 \\
51 \\
30 \\
15 \\
44 \\
30 \\
19 \\
61 \\
33\end{array}$ & $\begin{array}{r}\text { Percent } \\
11 \\
25 \\
15 \\
27 \\
3 \\
10 \\
20 \\
17 \\
14 \\
16 \\
30 \\
5 \\
34 \\
13\end{array}$ \\
\hline \multicolumn{4}{|c|}{ No addition (4.5 g starch per } & 74 & 60 & 45 \\
\hline
\end{tabular}

a Lanum, anhydrous lanolin.

b Lecithin, commercial grade recovered from soybean.

Figure 7 shows the effect of lecithin and lanum on the consistency of a sweetpotato-starch size, as compared with that of the original starch. One hundred $\mathrm{ml}$ of a lecithin-lanum solution were prepared containing $0.271 \mathrm{~g}$ of lecithin and $0.045 \mathrm{~g}$ of lanum. This solution was cooked with $4.5 \mathrm{~g}$ of sweetpotato starch at $90^{\circ} \mathrm{C}$. over a 6 -hour period. Consistency determinations were made at 1-3- and 6-hour intervals. The blank was made from $4.5 \mathrm{~g}$ of starch and $100 \mathrm{ml}$ of water under the same conditions.

These data show conclusively that colloidal solutions of lanum and lecithin added to sweetpotato size retard the breakdown of the size, especially at the lower cooking temperatures. The reason for this action is not yet understood.

\section{DISCUSSION}

This study shows that size from sweetpotato starch is in many ways similar to that from irish-potato starch, although it has several individual characteristics. Both starches, when made into size, seem 
to reach a maximum consistency during the early part of the cooking period, and gelatinization appears to be complete at this time; upon further cooking the consistency decreases until a minimum or waterlike consistency is reached. The change in consistency appears to be slower in sweetpotato-starch sizes than in those from irish-potato starch.

The latter is widely used in the textile industry as a sizing material and sweetpotato starch seems to have similar possibilities. The elimination, even partially, of the change in the consistency of potatostarch sizes would increase their value.

The present investigation has shown that this object can be attained in part at least, in the case of sweetpotato-starch size by the addition of lecithin and lanum. Further investigation may show other materials to be even more suitable for this purpose, especially from an

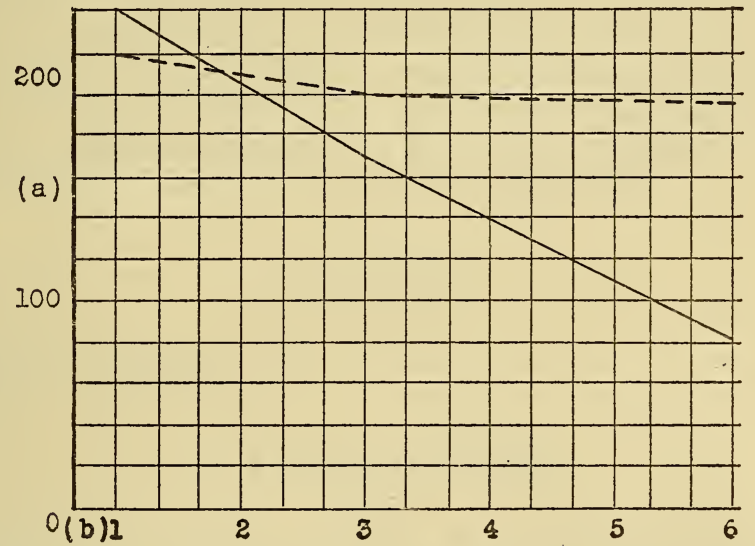

FIGURE 7.-Effect of addition of lecithin-lanum on consistency of sweetpotato-starch size.

(a) =Time of flow of $200 \mathrm{cc}$ through viscosimeter in seconds

(b) = Time of cook, hours

No addition to sweetpotato-starch size

- - - Lecithin-lanum added to sweetpotato-starch size

Cook temperature, $90^{\circ} \mathrm{C}$.

Speed of agitation, 150 r.p.m.

Time of cook, 1, 3, and 6 hours

economic viewpoint. The present cost of lecithin and lanum would probably limit their use as sizing ingredients. The prices of commodities, however, are not fixed and if larger consumption were assured lower prices might follow.

The important practical conclusions from this work are that the consistency of sweetpotato-starch size can be greatly increased (two fold to threefold) by washing with certain simple solutions, and that the breakdown of the size on heating can be considerably retarded.

Acknowledgment is hereby made to Edward Wolesensky for suggestions on the work and for assistance in the preparation of this paper for publication.

Washington, September 22, 1933. 